\title{
Issues Regarding the Early Development of Caddo Culture Discussion Topics for the East Texas Caddo Research Group, December 2008
}

Jeffery S. Girard

Northwestern State University of Louisiana

Follow this and additional works at: https://scholarworks.sfasu.edu/ita

Part of the American Material Culture Commons, Archaeological Anthropology Commons, Environmental Studies Commons, Other American Studies Commons, Other Arts and Humanities Commons, Other History of Art, Architecture, and Archaeology Commons, and the United States History Commons

Tell us how this article helped you.

This Article is brought to you for free and open access by the Center for Regional Heritage Research at SFA ScholarWorks. It has been accepted for inclusion in Index of Texas Archaeology: Open Access Gray Literature from the Lone Star State by an authorized editor of SFA ScholarWorks. For more information, please contact cdsscholarworks@sfasu.edu. 


\section{Issues Regarding the Early Development of Caddo Culture Discussion Topics for}

the East Texas Caddo Research Group, December 2008

\section{Creative Commons License}

\section{(c) (1) \&}

This work is licensed under a Creative Commons Attribution-NonCommercial 4.0 International License 


\title{
Issues Regarding the Early Development of Caddo Culture Discussion Topics for the East Texas Caddo Research Group, December 2008
}

\author{
Jeffrey S. Girard
}

\section{BASIC DEFINITIONAL PROBLEMS}

1. Is there a consensus regarding which archaeological traits are diagnostic of Caddo culture? What are the necessary and sufficient traits for designating a context as "Caddo" as opposed to, for example, "pre-Caddo" or "Coles Creek?"

\section{CHRONOLOGY}

1. When did diagnostic Caddo traits first appear in the archaeological record?

2. Were these traits linked or did they appear independently?

3. Were there temporal differences in the initial appearance of Caddo traits between upland environments and major floodplains?

4. What contemporary phenomena were ongoing in the Lower Mississippi Valley and elsewhere in the Southeast?

\section{SOCIAL, POLITICAL, AND ECONOMIC INTEGRATION}

1. Was there a "center" of Caddo development with subsequent diffusion to surrounding areas, or did Caddo traits emerge in multiple localities roughly contemporaneously as a result of social interactions?

2. How many early Caddo ceremonial centers (multiple mounds surrounding plazas) existed and where were they located?
3. How important was feasting or other ceremonial activities for integrating formerly diverse communities?

4. Did ceremonial centers develop at aggregated villages, or were they constructed as central places within existing dispersed communities?

5. Is there evidence for integration of multiple communities into larger "polities" or "chiefdoms?"

6. Were Caddo origins linked to changes in subsistence economies, particularly maize agriculture?

\section{SOCIAL AND POLITICAL HIERARCHIES}

1. Were early Caddo social hierarchies kinship based, or did leaders emerge as individuals, perhaps on the basis of warfare or economic achievements?

2. Did some early Caddo communities wield power and authority over others? Is there evidence of warfare and conflict between early Caddo communities?

3. Did the presence of social hierarchies elsewhere in the Southeast affect early Caddo developments?

4. How important was trade in exotic status goods for initiating and maintaining status differences in Early Caddo communities? Did the early Caddos participate in the Southeastern Ceremonial Complex? 


\section{THEORETICAL PERSPECTIVES}

1. Can the archaeological problem of Caddo origins be regarded as an example of the concept of "ethnogenesis" as developed in anthropological studies? Did a Caddo "ethnicity" exist prior to the time that we designate as Caddo in the archaeological record? Is "ethnicity" even a viable scientific concept useful for archaeological studies?
2. Should Caddo origins be considered a regional problem, or a problem only approachable as part of more widespread early Mississippian (or even broader) cultural developments?

3. To what degree are Caddo origins explainable in terms of "techno-environmental" issues? How important was the development of a distinct Caddo "ideology" and can we identify such in the archaeological record? 